\title{
JTE
}

Journal of Teachers of English

Volume 5 No. 1

e-ISSN: $2548-6810$

\section{THE EFFECT OF SILENT WAY METHOD ON THE STUDENTS' SPEAKING COMPETENCE AT THE TENTH GRADE OF SMAN 1 KONTUKOOWUNA}

\section{Wa Sani ${ }^{1}$}

Drs. Rohmana, M.Hum

Muh.Khusnun Muhsin, S.Pd.,MA

${ }^{1}$ Halu Oleo University, Indonesia.

\begin{tabular}{|c|c|}
\hline ARTICLE INFO & ABSTRACT \\
\hline Keywords: & The objective of the study was to find out whether or not the \\
\hline Speaking Competence, & silent way method can significantly affect students' speaking \\
\hline Silent Way Method & competence. The design of this study was a pre-experimental \\
\hline How to cite: & research design (one group pre-test post-test design). The \\
\hline & researcher applied a simple random sampling technique. The \\
\hline & class 10 IPA 1 was taken as the sample of the study with 18 \\
\hline \multirow[t]{13}{*}{ DOI: } & students. The instrument of this study was an oral test in pre- \\
\hline & test and post-test. This research was conducted through the \\
\hline & following procedures: giving a pre-test, applying treatments \\
\hline & and giving a post-test. The data were analyzed by using paired \\
\hline & sample t-test. Through the SPSS16.0 version. The result \\
\hline & showed that the mean score on students' speaking competence \\
\hline & in a pre-test was 32.22 and in the post-test was 49.44 . \\
\hline & Hypothesis testing found that the value of sig ( 2 tailed) was \\
\hline & 0.00 while the significant alpha value was 0.0 . It could be \\
\hline & concluded that the value of sig (2 tailed) was lower than the \\
\hline & significant alpha value was $(0.00<0.05)$. Therefore, H1 was \\
\hline & accepted and $\mathrm{H} 0$ was rejected. So, the use of the silent way \\
\hline & $\begin{array}{l}\text { method had a significant on the students' speaking } \\
\text { competence at the tenth grade of SMAN } 1 \text { Kontu kowuna. }\end{array}$ \\
\hline
\end{tabular}




\section{Introduction}

Speaking competence becomes the main objective of language learning especially in senior high school in Indonesia. Students of senior high school are required to master speaking after graduating from their school to be able to communicate in English. According to KTSP (School-Based Curriculum) of English for SMA, speaking must be taught to the students because it is one of the language skills besides reading, listening and writing. Moreover, students are expected to be able to communicate English well (Depdiknas 1994).

On the contrary, according to the writer's experience when I was in senior high school, speaking is the most difficult part for the students when they learn the English language. The writer found out many students of senior high school at SMAN 1 Kontukowuna still have difficulty in speaking English although they are supposed to master it after graduating from their schools to be able to communicate. Although students have learned English for years, many of them are still incapable to use English orally. These may be caused by the limitation of opportunity to practice, lack of vocabulary, psychological factors which more concern wit the fear of making mistakes when speaking English and also inappropriate method for the characteristic of the students.

to be able to speak English well, students have to feel comfortable and confident in practicing their English. By feeling comfortable and confident, students will not fear of making mistakes when speaking English. But on the other hand, many students always feel uncomfortable, unconfident, and fear of making mistakes when speaking English. This fear and uncomfortable feeling can be caused by the inappropriate method used by the teacher. There are many teachers use inappropriate methods in teaching speaking skill. They use a teaching method that makes their students fell unsecure, under pressure, and fear of making mistakes. Therefore, English teachers should be able to encourage and motivate the students to learn the target language by using the appropriate method. They should use an appropriate method that makes their students feel comfortable, independent, autonomous, and responsible.

The use of appropriate methods can influence the students' achievement in learning language, especially speaking skill in English. Anthony (1963) said that method is an overall plan for the orderly presentation of language material, no part of which contradicts and all of which is based upon, the selected approach. An approach is axiomatic, a method is procedural. It can be said that the method is the implementation of an approach. A method is a level at which theory is put into practice and at which choices are made about the particular skill to be taught, the content to be taught, and the order in which the content will be presented.

Wa Sani: 'I he Ettect of Silent Way Method Un the Students' Speaking Competence At the I'enth 
Setiadi (2006) says that there are many methods that can be applied in language teaching, such as Grammar Translation Method (GTM), Direct Method, Community Language Learning Method (CLM), Audio Lingual Method, Silent Way Method, Contextual Teaching and Learning (CTL), Total Physical Response, Suggestopedia, and Natural Approach. In this research, the writer is interested in using a silent way method in teaching speaking skills at the tenth grade of SMAN 1 Kontu Kowuna. She chooses that method because she assumes that the silent way method is a method that can encourage and motivate students to use their English without fell of fear in making a mistake.

Setiadi (2006:76) defines that in the Silent Way method, teaching-learning is facilitated if the students learn based on the self-correction. Therefore, this will make students independent, autonomous, and responsible. In this method, teachers have to make the students rely on themselves. The students can produce any sound and the teacher will never ask anybody else to do it for them. So, the students are hoped to be responsible for the words or utterances they are saying. Furthermore, in Silent Way the teacher functions as a guide, an organizer, a resource and as an evaluator.

Related to the result of the research in the Eleventh Grade Students at SMA N 1 Cepogo, Boyolali 2014/2015 Academic Years from Azwin Chris Prastawa and Sri Handayani had done research about Improving Students Speaking Skill Using Silent Way Method as a learning tool in EFL and the result of findings in the study suggested that the used of silent way method can contribute useful information for the future with the similar problem of speaking ability improvement and can be as information to the English teachers especially at SMAN 1 Kontu kowuna that silent way method can be applied in improving the students' speaking ability and also improve their performance in teaching. So, the different from the previous study and this research was research design. The previous study used classroom action research and this research used pre-experimental (pre-test-post test design).

Based on the result of the research, the writer concludes that teaching speaking skills through a silent way method has a positive effect on the students' speaking competence. This method encourages students to be more active in producing as much language as possible. It means that students have a great chance to practice their English language orally as much as possible to upgrade their speaking competence. Then, a language teacher encourages students to take a role in learning activities

\section{Methodology}

This study used pre-experimental with One-Group Pretest-Postest design to find out the effect of the silent way method on the students' speaking competence at the tenth grade of Wa Sani: The Effect of Silent Way Method On the Students' Speaking Competence At the Tenth 
SMAN 1 Kontu kowuna.. This study was conducted on 16th September 2019 until 30th September 2019. It was done at Senior High School 1 Kontukowuna. The sample of this study was class X IPA1.

The instrument of this research was an oral test in pre-test and post-test. The researcher took an oral pre-test at the first meeting in the experimental group to know the student's basic capability in speaking. Then, the researcher applied the silent way method in the experimental group for 3 meetings. After treatment, the researcher gave the oral post-test to know the improvement of student's speaking competence. The researcher took a video of the student's performance in front of the class to get accuracy and fluency.

The data from the pre-test and post-test were analyzed to find out whether the results of the tests are similar or different. To compare the result of the data from pre-test and post-test with the same subject, the writer used the paired sample t-test, and the data were calculated using SPSS (Statistical Package for Social Science) version 16.

\section{The Result of Research}

\section{Table 4.3 Descriptive statistics on pre test}

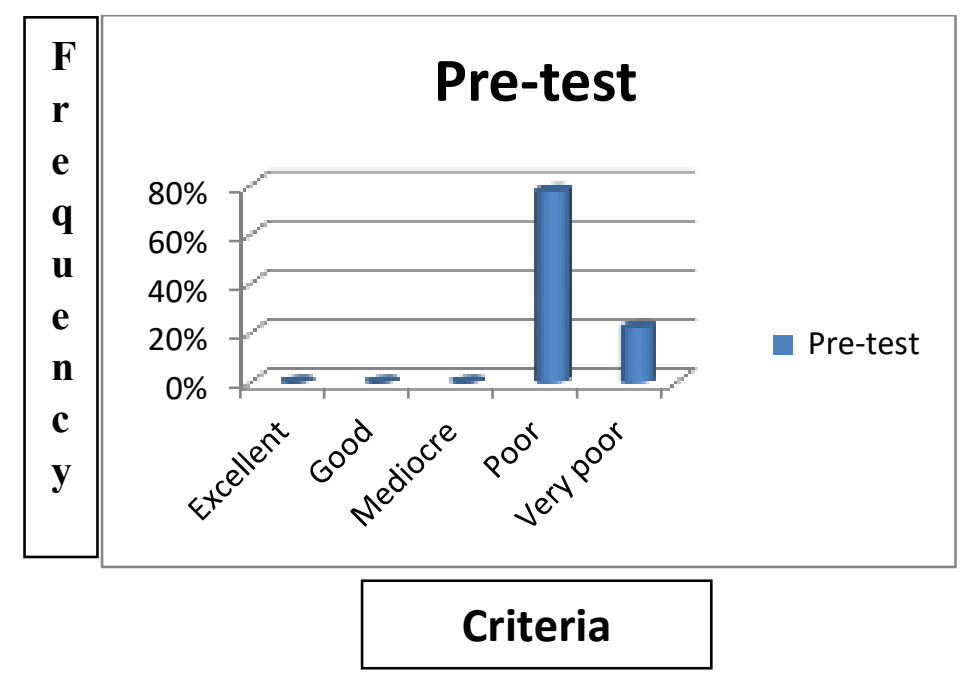

Based on the graph above, it can be interpreted that the students who get excellent criteria are 0 student $(0 \%)$, students who get good criteria is 0 student $(0 \%)$, students who get mediocre criteria is 0 student $(0 \%)$, students who get poor criteria are 14 students $(77.77 \%)$, students who get very poor criteria are 4 students $(22.22 \%)$. Then, it can be inferred that the largest frequency of students' scores on the pre-test is in "poor" criteria $(77.77 \%)$.

Table 4.2 Descriptive statistics on pre test 


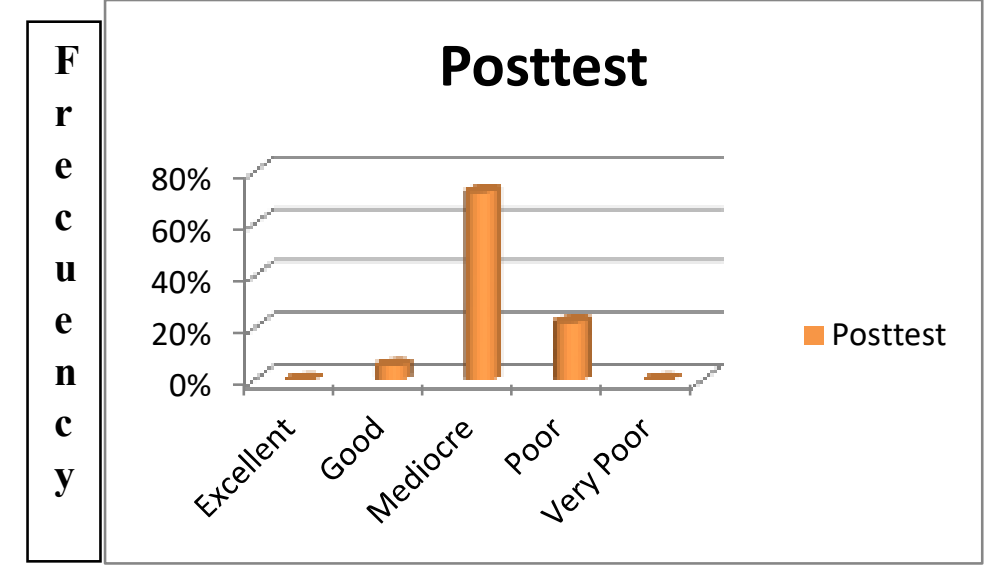

\section{Criteria}

Based on the graph above, it can be interpreted that the students who get excellent criteria are 0 students $(0 \%)$, students who get good criteria is 1 student $5.55 \%$, students who get mediocre criteria are 13 students $(72.22 \%)$, and students who get poor criteria are 4 students $(22.22 \%)$, students who get very poor criteria is 0 student $(0 \%)$. Then, it can be inferred that the largest frequency of students' scores on the post-test is "Moderate" criteria with $(72.22 \%)$.

Table 4.4 Normality Test

Tests of Normality

\begin{tabular}{|c|c|c|c|c|c|c|}
\hline & \multicolumn{3}{|c|}{ Kolmogorov-Smirnov ${ }^{\mathrm{a}}$} & \multicolumn{3}{c|}{ Shapiro-Wilk } \\
\cline { 2 - 7 } & Statistic & Df & Sig. & Statistic & df & Sig. \\
\hline Pretest & .192 & 18 & .080 & .862 & 18 & .013 \\
Posttest & .199 & 18 & .058 & .900 & 18 & .058 \\
\hline
\end{tabular}

Based on the result tests of normality Kolmogorov Smirnov above, it can be seen the value of the pre-test is 0.080 and the post-test is 0.058 . Both values from pre-test and posttest are bigger than the $\alpha$ value (0.05). The significant value on the pre-test is 0.080 and it is bigger than $0.05(0.080>0.05)$. Then, the significant value on the post-test is 0.058 and it is bigger than $0.05(0.058>0.05)$. It means that the data is a normal distribution. So, it can be concluded that both data ( pre-test and post-test) are a normal distribution.

Table 4.4 Paired Sample Statistic

Paired Samples Statistics 


\begin{tabular}{|rr|r|r|r|r|}
\hline & Mean & $\mathrm{N}$ & \multicolumn{1}{|c|}{ Std. Deviation } & \multicolumn{1}{|c|}{ Std. Error Mean } \\
\hline Pair 1 & Pretest & 31.1111 & 18 & 7.77544 & 1.83269 \\
& Posttest & 49.4444 & 18 & 6.83608 & 1.61128 \\
\hline
\end{tabular}

Based on the output of paired sample statistics above, it showed that the mean score of the pre-test is 31,11 while in post-test is 49,44 . Additionally, it also showed that the value of the standard deviation in the pre-test $(7,77)$ is higher than the value of standard deviation in the post-test $(6,83)$. It means that if the value of the standard deviation is high, it can be said that the sample data is more various. On the contrary, if the value of the standard deviation is low, it can be said that the sample data is more homogenous (almost the same). So, it can be inferred that from the table above, the sample data in the post-test is more homogenous (almost the same) than in the pre-test.

Table 4.5 Paired Sample Test

Paired Samples Test

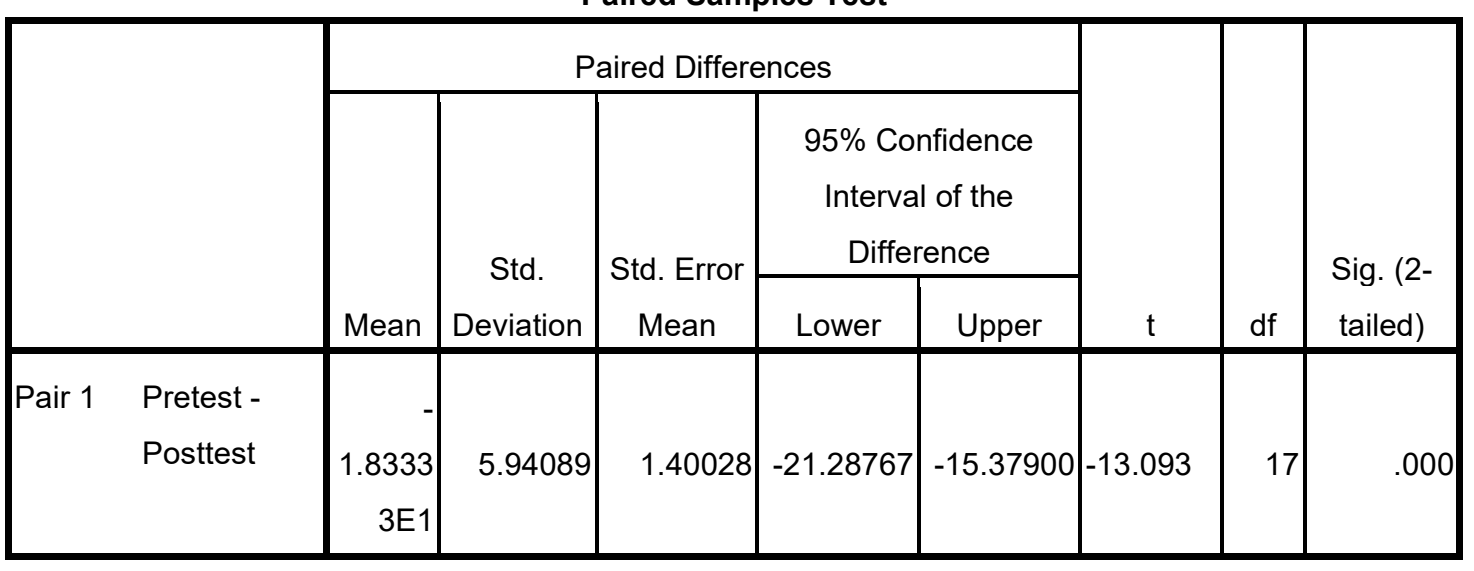

Based on the result of paired sample t-test above, it showed that significant differences exist in the students' pre and post-test scores, $\mathrm{t}(17)=-13.093$, sig. 2 tailed $(0.000)<0.05$ in posttest scores $(\mathrm{M}=49.44, \mathrm{SD}=6.83)$ are significantly higher than pre-test score $(\mathrm{M}=32.22$, SD 7.51). In conclusion, it can be said that there is a significant effect of using a silent way method on students' speaking competence at the tenth grade of SMAN 1 Kontu Kowuna. In other words, $\mathrm{H} 0$ is rejected while $\mathrm{H} 1$ is accepted.

\section{Discussion}

The result of findings shows that there is a significant effect by using a silent way method on the students' speaking competence. The silent way method allows students to Wa Sani: The Effect of Silent Way Method On the Students' Speaking Competence At the Tenth 
Journal of Teachers of English Vol. 5 No. 1

speak. Then, the students are not afraid to speak also they are confident to speak in front of the class. This statement supported by Setiadi (2006:76) defines that in the Silent Way method, teaching-learning is facilitated if the students learn based on self-correction. It means that the students feel independence to speak without feel afraid to the teacher. Therefore, the teacher can achieve the goals of these learning.

Richard and Rodgers (1986:109 - 110) describes that in teaching speaking skill with silent way method at the beginning of the stage teacher will model the appropriate sound after pointing to a symbol on a chart. It means that an assignment of the teacher just points to a chart and the students describe what the teacher points. The teacher will describe to them if all the students cannot explain to her friends. After that, the students describe pictures one by one in front of the class. When the students do not know what to say the teacher shows the number to help students to get the students mean. Therefore, the teacher guides them to get the objective of this lesson.

Besides, this study has been proved that there is a positive effect on students' speaking competence before and after silent way method at the tenth grade students of SMAN 1 Kontu Kowuna because of some factors. Those factors are students' motivation, interesting topic, and a group work activity. The first factor is the students' motivation. Relating to the students' motivation in learning English, Wang (2009:98) states that “the important factors that can influence students' achievement and English performance are motivation". Students who are motivated to learn English tend to have a more positive attitude to learn. So, they can spend their time with their friends to practice speak up in English so that their speaking competence is better than before. During the teaching and learning process some students showed a positive attitude, they also more active and more pay attention to the teachers' explanation. The students ask her teacher if she does not understand what the teacher means.

When implementing this method, the researcher find out that students' motivation is improved when they learned by using silent way method. It happens because this method allow speaking, the students feel independent and they are not afraid to speak so that students can talk with her friends. It is assumed that the use of silent way method can improve the quality of teaching and learning process because this method stimulates students to dominate the class (students-centered), become more active, and get high participation in the class. According to Deliana (2007), students must practice more to get improved speaking competence. Because by practicing, it can encourage students to speak a lot in the classroom and become more active. Therefore, students' motivation is increased through silent way method. 
The second factor is the topics given during the study are interesting. According to Ur (1996: 120) "Learner is eager to speak because they are interested in the topic ". Students is interested in learning and speaking English when they interested in the topic given and appropriate with their level. It is supported by Nation and Newton (2008: 152-153) "The learners take part in activities where all the items are within their previous experience". It means that, an interesting topic has crucial role for the students because the teacher provides three topics mainly describing people, tourist attraction, and historic sites. Based on the topics the students are happy in learning English so that way their speaking competence are improved. Therefore, to improve speaking competence the teacher should give an appropriate topics for the students in order the students are not boring in the class.

The last, students work with their friends with way make a group work in the class to improve their speaking competence. So, they can talk with their partner group so that the teacher is easy to teach them because if the students doesn't know what to say, the students can ask her partner group then back to the teacher. Group work is helpfull students because they do not work alone also they are not boring in the class. Therefore, to improve speaking competence the teacher should used group work in the class.

As a result of their report on post-test most of them are good. They can produce accuracy and fluency in good criteria. In this meeting, the students also start talking well. To know their ability, the teacher points students one by one to come in front of the room to describe picture. The student is describing well. Every student has the same opportunity to describe the picture. So, the teacher knows their ability. Therefore, the way of the teacher to teach students is more crucial than much speaks without action.

Setiadi (2006:76) says that the teacher functions as a guide, an organizer, a resource, and evaluator. It means that when the teacher teaches the students by using silent way method, the teacher works by her gesture and stimulates them. By looking at the students' activities in the learning process, students are accustomed to do the talking activity. So, at the last meeting, students can reduce anxiety and fear in describing their school. That is the reason for significant effect of silent way method on the students' speaking competence.

Applying silent way method in teaching speaking can help the students' speaking competence. It makes students interesting to learn. Also all students had chance to speak in the class. Before conducting silent way method in the teaching of speaking, students are shy, frightened and poor vocabulary to speak in English. Students can reduce their shy, frightened and poor vocabulary to speak. All the time in teaching through silent way method, students try to use English in describing of the object. If the students doesn't know when they speak, she can ask her friend and the teacher explains to them if her friend doesn't know too. So, in Wa Sani: The Effect of Silent Way Method On the Students' Speaking Competence At the Tenth 
Journal of Teachers of English Vol. 5 No. 1

the last meeting, they can produce a good conversation. Most of them can speak fluently and accurately in the last meeting (post test). The ability to speak in a post-test session is better than a pre-test session.

Based on the finding above, it can be concluded that silent way method has a positive effect on students' speaking competence. The result of this research is silent way methode effect students' speaking competence and atittude toward English and also the result of this research showed that through silent way method, students' fluency and accuracy have been improved significantly. Not only her ability have improved but also their confidences and the students are not afraid when they are speaking in front of their friends.

\section{Conclusion and Recommendation}

Based on the research question and hypothesis, the researcher concludes that there is a significant effect of using silent way method on students' speaking competence at the tenth grade of SMAN 1 Kontu Kowuna. The result of data analysis showed that the mean score in pre-test is 32.22 while the mean score in post-test is 49.44 . The score is increased of applying silent way method in teaching speaking. The standard deviation in pre-test is 7.51 and in post-test is 6.83 . In pre-test, the students who get poor criteria are 14 students or $77.77 \%$. There is no students who get excellent, good, and mediocre criteria. In post-test, students who get good criteria is 1 student or $5.55 \%$. Students who get mediocre criteria are 13 students or $72.22 \%$. Students who get poor criteria are 4 students or $22.22 \%$. No student get excellent and very poor criteria.

The result of hypothesis testing is $\mathrm{H} 0$ rejected and $\mathrm{H} 1$ is accepted. It means that there is any significant effect of using silent way method on the students' speaking competence at the tenth grade of SMAN 1 Kontu Kowuna. It can be seen from the value of sig (2 tailed) was smaller than the alpha value $(0.000<0,05)$. Silent way method can effect students' speaking competence because this method allows speaking, the students feel independence and they are not afraid when speaking in front of the class.

\section{Recommendation}

Based on the results of this researcher, the researcher recommended as follows:

1. Teaching speaking using Silent Way Method might be continued by further research to higher level, like University level.

2. The teacher of English at school can use Silent way Method in their teaching learning process to upgrade students' speaking competence. 


\section{References}

Antony, Edward M. 1963 . “Approach, Method, and Technique”. English Learning 17:63-67 Ann Arbor: University of Michigan Press.

Deliana. (2007). The Influence of the Ability in Mastering dialogue on the Achievement in Learning English. Thesis. Surabaya:UNS.

Departemen Pendidikan dan Kebudayaan RT. 1994. Garis - garis Besar

Pengajaran Kurikulum SMA. Depdikbut. Jakarta

Nation, I. S. P., \& Newton, J. (2008). Teaching ESL/EFL Listening and Speaking: Routledge. Richards, Jack C and Rodgers, S. Theodore. 1986. Approaches and Methods in

Language Teaching. Cambridge: Cambridge University Press. 
Setiyadi Bambang. 2006. Metode Penelitian Untuk Pengajaran Bahasa Asing,

Pendekatan Kuantitatif dan Kualitatif. Graha Ilmu. Yogyakarta.

Ur, P. (1996). A Course in Language Learning: Practice and Theory. Cambridge: Cambridge University Press.

Wang, B. (2009). Motivation and Language Learning. Asian Social Science, 5(1), 98. 